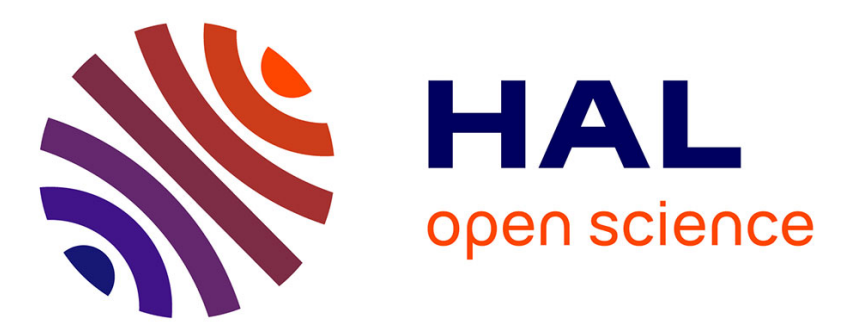

\title{
SMS length and function: A comparative study of 13- to 18-year-old girls and boys
}

Antonine Goumi, Olga Volckaert-Legrier, Alain Bert-Erboul, Josie Bernicot

\section{To cite this version:}

Antonine Goumi, Olga Volckaert-Legrier, Alain Bert-Erboul, Josie Bernicot. SMS length and function: A comparative study of 13- to 18-year-old girls and boys. European Review of Applied Psychology / Revue Européenne de Psychologie Appliquée, 2011, 61, 10.1016/j.erap.2011.07.001 . hal-01392507

\section{HAL Id: hal-01392507 https://hal.science/hal-01392507}

Submitted on 4 Nov 2016

HAL is a multi-disciplinary open access archive for the deposit and dissemination of scientific research documents, whether they are published or not. The documents may come from teaching and research institutions in France or abroad, or from public or private research centers.
L'archive ouverte pluridisciplinaire HAL, est destinée au dépôt et à la diffusion de documents scientifiques de niveau recherche, publiés ou non, émanant des établissements d'enseignement et de recherche français ou étrangers, des laboratoires publics ou privés. 


\section{PRE-PRINT}

Goumi, A., Volckaert-Legrier, O., Bert-Erboul, A. \& Bernicot, J. (2011). SMS length and function: a comparative study of 13 to 18 year-old girls and boys. European Review of Applied Psychology, 61(4), 175-184.

SMS length and function: a comparative study of 13- to 18-year-old girls and boys

Longueur et fonction des SMS : étude comparative chez les filles et les garçons de 13 à 18 ans

Antonine Goumi ${ }^{1}$, Olga Volckaert-Legrier ${ }^{2}$, Alain Bert-Erboul ${ }^{1}$, and Josie Bernicot ${ }^{1}$

Addresses for correspondence:

1. Université de Poitiers-CNRS, Centre de Recherches sur la Cognition et l'Apprentissage (CeRCA), MSHS Bâtiment A5, 5 rue Théodore Lefebvre, F-86000 POITIERS, France antoninegoumi@gmail.com; Phone: +33 (0) 5.49.45.46.83 - Fax: +33 (0) 5.49.45.46.16 josie.bernicot@univ-poitiers.fr; alainberterboul@gmail.com

2. Laboratoire PDPS Axe 4 - Psychologie des acquisitions et des apprentissages 5 allées Antonio Machado 31058 TOULOUSE Cedex 9, France olga.volckaert-legrier@univ-tlse2.fr 


\begin{abstract}
Objective - The use of SMS messaging has grown rapidly over the past decade. Up until now, most French-language studies have focused on one predominant SMS characteristic: spelling. The goal of this paper is to extend previous research topics so as to include new dependant variables such as message length and message functions.

Method - A corpus of 1131 SMSes produced in a natural environment by teenage French speakers was analysed. This group was made up of teenage girls and boys between the ages of 13 and 18 who reported frequent usage of SMS messaging over an extended period of time. Did these SMS exchanges confirm stereotypes regarding gender differences? That is, did girls produce longer messages than boys? Did girls send more messages with a relational function than with an informational function, while boys did just the opposite?

Results - The results led to a mitigation of these stereotypes. Girls did produce longer messages than boys. However, this only occurred when the girls were 15-16 years of age and had a longstanding and frequent practice of SMS usage. Regarding functions, girls' messages more often had a relational function than an informational one, but again, only in girls who were 15-16 years of age and had been SMSing frequently for a long period of time. In boys, it took until 17-18 years of age for the same result to appear. More than a gender difference, these results emphasized a discrepancy in the developmental curves of girls and boys, girls being more precocious than boys.
\end{abstract}

Keywords: Text messaging - Teenagers - French language - Writing - Communicative functions - Gender - Text messaging experience 


\section{Résumé}

L'utilisation du SMS s'est développée très rapidement au cours de la dernière décennie. Les études déjà réalisées en langue française mettent l'accent sur l'une des caractéristiques prédominantes des SMS : l'orthographe. L'objectif de cet article est d'approfondir les questions de recherche avec d'autres variables dépendantes comme la longueur et la fonction des messages. On analyse un corpus de 1131 SMS produits en situation naturelle par des adolescents francophones de 13 à 18 ans (filles et garçons) ayant une pratique plus ou moins ancienne et fréquente de l'usage des SMS. Les stéréotypes concernant les différences filles/garçons se vérifient-ils lors de la communication par SMS ? Les filles produisent-elles une quantité de paroles plus importante que les garçons ? Envoient-elles plus de messages à fonction relationnelle qu'à fonction informationnelle alors que les garçons feraient l'inverse ? Les résultats conduisent à atténuer ces stéréotypes. Les filles produisent des messages plus longs que les garçons mais uniquement à 15-16 ans et lorsqu'elles ont une pratique ancienne et fréquente des SMS. Pour la fonction des messages, ceux des filles ont plus souvent une fonction relationnelle qu'informationnelle mais là encore, uniquement à 15-16 ans et pour une pratique ancienne et fréquente ; ce même résultat n'apparaît chez les garçons qu'à 17-18 ans. Plus qu'une différence entre filles et garçons, ces résultats mettent en évidence un décalage dans leurs courbes développementales : les filles étant plus «précoces » que les garçons.

Mots clés : Messages SMS - Adolescents - Langue française - Langue écrite - Fonctions communicatives - Genre - Pratique des messages SMS 


\section{Introduction}

Language, whether oral or written, facilitates the transmission and expression of a great many things such as messages, information, practices, relationships, and emotions. The technological environments in which we now live reinforce this indefatigable source of information transfer (such as, for example, the mobile phone, which makes it possible to send SMSes). Furthermore, our society is also filled with stereotypes, especially those concerning men and women.

\subsection{Language, women, and men}

It is typical for women to be thought of as more talkative than men, more "verbal", and tending to use language for relational or expressive ends, etc. On the other hand, men are considered more "practical", essentially using language to transfer more useful information. The link between language and gender has been extensively studied within Anglophone literature (Gleason \& Ely, 2002; Halpern, 2000; Wood, 2001). Research by Leaper and Smith (2004) revealed that girls were more talkative and used more "relational"-type expressions than boys who, for their part, used an "assertive"-type language. It has also been shown that boys consider themselves less able to show emotion-based expressions (sharing of self, empathy), while girls feel that they are more capable than boys of showing their abilities with regard to expressing feelings (Michaud, Bégin, \& McDuff, 2006). Additionally, teenage girls are thought to have a more developed "emotional contagion" than teenage boys, while the latter supposedly demonstrate greater "emotional cut-off" than the former (Favre, Joly, Reynaud, \& Salvador, 2009). If, then, it is typical to think that girls are more talkative and "emotional" than boys, and that boys are more "practical" than girls, the research results seem to confirm these stereotypes. 


\subsection{SMS language}

Since 1635, and all the way until quite recently, written French was regulated by a standard set by the Académie Française and dictionaries. This traditional written language, of great importance, is learned at school and is the gateway to knowledge. In spoken language, certain differences of expression are accepted, albeit with more or less difficulty (formal/informal, colloquial/not colloquial, baby talk, slang, etc.). Deviating from the standard written form is a totally new phenomenon (Gadet, 2007), as is the use of written language used within daily inter-individual relations, outside of academic, professional or administrative situations. This new communication register induced by new technologies in fact creates a societal problem with regard to the standard of written language. The $\mathrm{SMS}^{1}$ is one of these new communication technologies. In a matter of just a few years, written communication by SMS has not only entered into our everyday life, but has become an increasingly important part of it. This readily accessible technology enables asynchronous remote communication between individuals. Within seconds, a 160-character SMS message can be sent from a mobile phone to another computer or mobile phone anywhere across the globe. Less "intrusive" than phone calls, SMS messages are inexpensive and their use is nearly synchronous, like traditional oral communication, while remaining asynchronous like traditional writing. Since the year 2000, the use of SMS messaging, along with other computer-mediated forms of communication ${ }^{2}$ such as e-mail, instant messaging (chat), and online help forums (Danet \& Herring, 2007; Puustinen, Bernicot \& Bert-Erboul, 2011; Puustinen, Volckaert-Legrier, Coquin, \& Bernicot, 2009), has exploded. In the 2001 edition of his book, Language and the Internet, Crystal spent two pages discussing SMS use, and dedicated an entire book to the subject in 2008.

\footnotetext{
${ }^{1}$ SMS is the abbreviation of Short Message Service.

2 We use the terminology of Panckhurst (1997). Other terms exist to define analogous realities: "electronic communication", "mediated electronic communication" or "computer mediated communication" (CMC in international literature).
} 
Studies carried out on French-speaking populations have confirmed the massive use of text messaging by adolescents. A study by Leo and Wolf ${ }^{3}$ (2004) and another by Samsung in 2006 in Belgium, found that $75 \%$ of the Belgian population owned a mobile phone. For $45 \%$ of Belgians, the exclusive function of a mobile phone was to make phone calls and send SMSes. Furthermore, $90 \%$ of those aged 15-35 used the SMS function. In France, according to the CREDOC study (Bigot \& Croutte, 2009), the proportion of mobile phone users rose from $24 \%$ in 1999 to $82 \%$ in 2009. In 2003, 57\% of mobile phone owners used the SMS function; in 2009, this proportion had reached $74 \%$. The younger the person, the more SMSes are used to communicate: $100 \%$ of young people between the ages of $12-17$ sent SMSes, $68 \%$ of those aged $40-59$ and only $21 \%$ of people over 70 years of age made use of this mobile phone function. The average weekly number of SMSes sent lies between 19 and 30. Crystal (2008) and Thurlow and Poff (2009) describe the same type of situation across different countries and different languages: the United States, the United Kingdom, Finland, Sweden, Norway, Germany, Italy, South Africa, Nigeria, New Zealand, Kuwait, Malaysia, Japan, Korea, China, Taiwan and Hong Kong.

From a scientific point of view, the study of SMSes is providing new data with which to answer questions regarding language acquisition and use. This novel linguistic material is of particular interest from a pragmatic perspective where the goal is to link the characteristics of linguistic production with their communicative situations (Austin, 1962; Bernicot, 1994; Bernicot, Comeau \& Feider, 1994; Bernicot, Laval \& Chaminaud, 2007; Grice, 1975; Noveck \& Sperber, 2004; Searle, 1969; Verschueren, 1999). These studies seek to determine the linguistic specificities of SMSes defined as a register (Ravid \& Tolchinski, 2002) of written communication. Along these same lines, Crystal (2001) emphasised the importance of the concept of "language variety" which can be applied to oral and written language, legal language, scientific language, regional particularities of a

\footnotetext{
${ }^{3}$ Company specialised in mobile marketing.
} 
language, literature and also to computer-mediated writing, including SMSes. These variations are systematic, predictable and conventional. While giving a lecture, a university professor would not be expected to speak in the same way as a sports commentator reporting a televised football match. In the same way, it would not make sense to expect the SMSes written by teenagers to resemble the written language such students use in an academic setting. The SMS messages will surely display different graphical, orthographical, and grammatical traits as well as an organisation of discourse which deviates from the standard form (Crystal, 2001). SMSes are also able to fulfil different social functions.

Research concerning SMS messaging has revealed a great deal about the most obvious characteristic of SMSes: the use of orthographic forms which differ from those found in traditional writing. The specific spelling forms which have been inventoried are essentially neographic forms resulting from puzzlegrams or the use of homophonic letters and numbers, phonological reductions, symbols, and acronyms (Crystal, 2008; Frehner, 2008). In this vein, many studies have specifically focused on the French language (Anis, 2007; Bouillaud, Chanquoy \& Gombert, 2007; Fairon \& Klein, 2010; Liénard, 2005, 2007; Panckhurst, 2009; Rivière \& Licoppe, 2005; Véronis \& Guimier de Neef, 2006) and, like the first research carried out on oral language in the early $19^{\text {th }}$ (McCarthy, 1954), have also highlighted the gender differences between girls and boys. In the area of computermediated writing, girls, as compared to boys, use SMS messaging more frequently, and send longer and more complex messages including more "emotional" content (Thurlow \& Poff, 2009).

There are now sufficient available data to go beyond these most obvious orthographic traits of SMSes and focus in on the other questions being examined in this area of research. One Frenchlanguage study (Rivière \& Licoppe, 2005) led the way by focussing on the addressees of SMS messages: SMSes are usually sent to close friends, no matter the age of the mobile phone user. The authors stressed the frequency of within-family SMS use between parents and their children, and 
the more limited use of SMSes in formal or professional settings. Emotional messages made up the majority of the exchanges.

By working with a large corpus of SMSes collected in a natural situation (Fairon, Klein \& Paumier, 2006) by teenagers between the ages of 13-18, we examined the role of the writers' characteristics (age, gender, and SMS experience) on the length of the SMSes they sent. We also studied the functions of SMS messages (informative or relational). The objective was to show the extent to which the length and functions of SMSes varied according to the characteristics of the writers.

\subsection{Prior Research}

The majority of studies carried out on SMS messaging have primarily been interested in the orthographic characteristics of the messages. However, a few studies have also analysed such measures as the length of messages and their functions.

SMS length - SMS messages contain a maximum of 160 characters. How do teenagers use this space? Does age play a role? Are there differences between girls and boys? Does SMS messaging frequency or experience play any role?

In the UK, Grinter and Eldrige (2001) collected the SMS messages of five boys and five girls between the ages of 15-16 (who were paid to participate). The teenagers were asked to copy down on a form all the SMSes they had sent and received over the past seven consecutive days. The mean length of the 236 messages was 71 characters.

Thurlow and Brown (2003) analysed the data collected in the UK by Brown (2002) from 70 participants with a mean age of 19 . At the end of a class, students were asked to fill out a questionnaire detailing their use of mobile phones and new technologies, as well as to transcribe 
five SMS messages received or sent during the previous week. The mean length of the 544 messages analysed was 65 characters and 14 words. Hård af Segerstad (2005) and Döring, Hellwig and Klimsa (2005) found similar results with Swedish and German participants, respectively.

In a telephone survey in 2002, Ling (2005b) analysed 882 messages collected from 463 Norwegian participants between the ages of 13 and 67. The participants were asked, along with questions concerning their mobile phone use, to provide the exact text of the last SMSes they had sent. The average number of words per SMS was 5.54 for the men and 6.95 for the women. The author also analysed the complexity of the messages as defined by the number of sentences, propositions or distinct thoughts. Of the messages sent by women, $40 \%$ were complex (containing more than one sentence), compared with $26 \%$ for men. The group of 16 - to 19-year-old teenage girls wrote the greatest number of complex messages (51\% as compared to $15 \%$ for boys of the same age).

Ling (2005a) presented data collected in 2004 from 1000 Norwegian participants between the ages of 13 and 67 via the telephone survey method already used by Ling (2005b). The author collected 417 messages (written with or without the use of the T9 predictive text function) with an average length of 29 letters and approximately 6 words. For the 13- to 34-year-old age group (including a 13- to 15-year-old group and a 16- to 19-year-old group), girls wrote longer messages than boys (30 and 20 letters, respectively). Between 34 and 54 years of age, both men and women sent messages containing 20 letters, while from 54 to 67 years of age, the number of letters rose for women (25 letters) and decreased for men (10 letters). When looking at the broadest age range of 13-67, a decrease in the number of letters per message (from 25 to 17.5) can be observed, with 34 years of age as the tipping point.

Deumert and Masinyana (2008) examined SMSes which were collected in 2006 from 22 participants in South Africa; the participants ranged in age from 18-27, were bilingual speakers of 
isiXhosa and English and came from the same social circle as the researchers. The authors asked the participants to transcribe (or send directly to the researcher) all the messages they had sent throughout the previous week. The 312 messages in total were written either in one or the other language, or in a mixture of both. The average length of the messages was 133 characters and 22.6 words, with girls writing 23 words, and boys, 19 words.

In each of the prior studies, the same methodological problem was encountered: the technical impossibility of directly collecting the SMSes as a computer file, and thereby the need to copy down a fleeting text. This created an overall problem with regard to the reliability of the corpus (the researchers did not possess the original messages) and the representativeness of the recopied messages (the risk of an over-representation of short messages, which are easier to recopy). The results varied according to the method used: working with a small group of participants known to the researchers, or via a telephone survey carried out with a large number of participants. In the first case, the collected messages were 65-133 characters and 14-22 words in length, while in the second case, the collected messages were 29 letters and 6 words in length. Data were collected in English, Norwegian and isiXhossa. Prior researches gave information neither on the role of age during the period of adolescence (13-18) nor on the level of SMS messaging or experience with computermediated communication on the evolution of data. As far as this period is concerned, Ling's (2005a and 2005b) research emphasises that girls write longer and more complex messages than boys.

SMS functions - What is the purpose of SMSes? What are they sent to say (or to do)? The studies conducted in this area do not adhere to the strict viewpoint of pragmatic theories which attempt to determine the writer's intention (the illocutionary value of the message) according to a taxonomy containing a limited number of theoretically justified categories, such as the five-act taxonomy of Searle \& Vanderveken (1985). Rather, the research on this topic takes an empirical 
point of view, constructing categories of ad-hoc social functions which are interesting for daily life, but whose theoretical meaning or psychological pertinence are at times debatable.

In the study by Grinter and Eldridge (2001), the authors sought to answer the question "What are text messages used for?" with four categories: arranging times to chat on the computer $(25 \%)$, coordinating activities with friends (26\%), chatting and gossiping (39\%), co-ordinating activities with family (10\%). One message, according to the authors, could fulfil several functions, and no difficulties were observed in the coding of the functions in question.

In another previously-mentioned study, Thurlow and Brown (2003) stressed the multifunctional nature of text messages while showing that the 544 messages could be categorised by their principal function. They presented a helpful grid with two axes: an informational-transactional axis (practical information and organisation, chain letters) and a relational axis (social organisation, greetings, friendly, romantic, and sexual relationships). Of the 544 messages, $31 \%$ fell under the first category, while $61 \%$ were in the second category.

In 2003, Döring et al. (2005) conducted a study in Germany via a survey on SMS use (482 participants between the ages of 12-18 completed the survey). Girls were significantly more generous than boys in their declarations of friendship and love. Compared with boys, girls wrote and received more text messages containing emotional content when they were experiencing difficulties. Kasesniemi (2003) found similar results with Finnish teenagers: girls had far more SMS exchanges concerning emotional topics, while boys sent messages of a more practical nature, dealing with facts and events.

Faulkner and Culvin (2005) worked in the UK with 24 students who were all 20 years old. Each participant was asked to transcribe on a form, for a period of two weeks, all the text messages they sent and received on their mobile phone. The total of 337 SMSes included in the database, from 1320.5 characters in length, were then analysed by coders according to their functions. The coders 
were given a large number of categories (15) ranging from advertising to news and including appointments, gossip, jokes and reminders. These results must to be taken with a certain degree of caution however, as the authors noted that consensus on the choice of categorisation was only reached for $15.74 \%$ of the messages (53/337). Nonetheless, this study's findings are interesting in that they suggest that a large proportion of text messages have a relational function.

Ling (2005b), in an aforementioned study, also studied the functions of SMS messaging. The author presented a grid separated into 7 categories: The greatest number of messages, 30\%, dealt with making arrangements for daily activities (i.e., "Could you pick up the children from day care?"). This was followed, in decreasing order, by grooming-related messages (i.e., "Good night sex bomb") (17\%), simple responses (i.e., "yes" or "no") (14\%), questions (11\%), information (6\%), instructions and requests (6\%), and personal news (5\%). The author did not make note of any coding difficulties.

Deumert and Masinyana (2008), in a study mentioned above, also examined the different functions of SMSes. Almost half the messages sent had to do with friendly relations. Next came love-related messages with close to $20 \%$, informational messages (15\%), practical and social organisation (10\%), and chain letters $(7 \%)$. Here, too, the authors did not mention any coding difficulties.

Overall, the research conducted up until now have used various categories to analyse the functions of SMS messages. The only study to present a between-coder agreement rate (Faulkner \& Culvin, 2005) showed a very low rate (15\%), thus bringing to light potential problems related to the choice of categories and their definitions.

However, all of the research found consensus on one important point: the importance of the "social-relations" function in the use of SMS messaging. Messages relating to friendly relations are sent frequently and, according to some authors, especially by teenage girls. The proposition made 
by Thurlow and Brown (2003) to place the different functions along an axis ranging from more informational to more relational and intimate is certainly an interesting path along which to move forward with this topic.

\subsection{Study aims}

The first aim of our study was to analyse a large corpus of French-language SMSes collected using a method (Fairon et al., 2006) which could guarantee the ecological validity of the messages (over 1000 SMSes produced by about 100 participants). Only limited research data on SMS language usage currently exist for French-speaking population. The second objective was to focus specifically on the adolescent years (ages 13-18). Information concerning this age range does indeed exist, but the existing data are vague or contradictory, despite the fact that SMS messaging is used by these individuals the most. Furthermore, 13- to 18-year-old teenagers are still in the process of acquiring conventional written language (Berman, 2005). This study was designed to find out whether this was the same in terms of SMS writing. So as to define each developmental stage with precision, the participants were separated into one-year age groups: ages 13-14, 15-16, and 17-18. The third aim was to shed light on the influence of the participants' characteristics, such as gender (girl/boy) or text messaging experience (how long and how frequently he/she had used SMSes), on SMS language use. While previous research had considered the three variables separately, this study crossed the variables (age, gender, and experience) in order to arrive at the research design. The length of SMS experience and the frequency of texting were not taken into account in the existing research, despite the fact that their role had been evoked with regard to other modes of computer-mediated communication such as e-mail (Volckaert-Legrier, Bernicot \& Bert-Erboul, 2009). We sought to determine whether the differences between girls and boys which were revealed by Ling (2005a and 2005b), Döring et al. (2005) and Kasesniemi (2003) vary according to age and 
SMS experience. Specifically, do girls always send longer messages with more emotional functions than boys do?

In this study, we chose to concentrate on variables other than spelling, yet just as important in the characterisation of SMSes. First, we examined the length of SMSes, as the available data on this topic are contradictory. The length of text messages is a classic index providing information on how the 160 available characters per SMS are used by text writers. Depending on the individual study (Deumert \& Masinyana, 2008; Grinter \& Eldridge, 2001; Ling 2005a and 2005b; Thurlow \& Brown, 2003), results varied from collected messages which were relatively short (29 letters and 6 words) to messages which were relatively long (65 to 133 characters and 14 to 22 words). A better understanding of the communicative functions of text messages was also sought: The existing research (Deumert \& Masinyana, 2008; Faulkner \& Culvin, 2005; Grinter \& Eldridge, 2001; Ling 2005b; Thurlow \& Brown, 2003) has shown that these functions are more relational than informational. The messages were then separated into detailed categories.

\section{Method}

At the Catholic University of Leuven, Belgium, two research centres, the Centre for Automatic Language Processing (CENTAL) and the Centre for Studies on Romance Lexicons (CELEXROM)

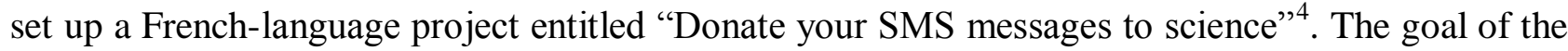
project was to create a corpus of text messages for research in the fields of linguistics and linguistic engineering. In order to participate in this project, individuals needed to forward SMSes of their choice to a free telephone number, and, in addition, to fill out a sociolinguistic questionnaire detailing the donors' characteristics (age, gender, education level, occupation, etc.) and SMS

\footnotetext{
${ }^{4} \mathrm{http}: / /$ www.sms4science.org/
} 
messaging experience. This project resulted in the creation of a corpus of 30,000 SMSes collected from 2436 donors (Fairon et al., 2006).

\subsection{Participants}

From the complete "Donate your SMS messages to science" corpus, 115 participants were selected according to the following criteria:

(a) Language: the participants had to be monolingual French-speakers;

(b) Age: the participants had to be between the ages of 13-18. They were separated into three age groups: $13-14,15-16$, and 17-18 years of age;

(c) Gender: the participant group was made up of 54 boys and 61 girls;

(d) SMS experience, measured by how long and how frequently the participant had been texting. Here, participants were split into two contrasting groups: one, which had been texting frequently for an extended period of time, and the other, which had only recently begun texting, and did not text frequently. To be placed in the experienced, or Eof (old/frequent experience), group, a participant needed to have been using SMS messaging for more than three years and sending more than 10 text messages (between 10-100) per week. To be placed in the inexperienced, or Err (recent/rare experience), group, a participant needed to have been using SMS messaging for less than three years (0-3 years) and sending less than 10 text messages per week.

All of the data used to compile the sample (age, language, experience, and gender) were supplied by the questionnaires completed by the SMS donors. Table 1 shows the number of participants by age, gender, and experience. All of the participants in the database who met our criteria were retained except for the 18-year-old participants who had been texting frequently for many years (Eof); out of a desire to keep the groups balanced, out of the 30 total participants, only the first 18 
were included in the sample. Table A1 in Appendix A explains in detail the number of participants in the two groups (old/frequent and recent/rare experience) in terms of the number of SMSes sent.

\section{Insert Table 1}

\subsection{SMS messages}

All SMSes submitted to the corpus were retained ${ }^{5}$. The number of messages varied from 1 to 59 for the participants who were experienced in texting and 1 to 26 for the inexperienced participants ${ }^{6}$. Table 1 summarizes the number of messages according to age, gender and texting experience.

A total of 802 messages were collected from experienced (old/frequent) participants (an average of 11.62 messages per participant) and 329 messages from the inexperienced (recent/rare) participants (an average of 7.15 messages per participant). Furthermore, there were 476 messages for 54 boys (an average of 8.81 messages per participant) and 655 messages for 61 girls (an average of 10.74 messages per participant).

The data collection method upon which this study's corpus was based could put its representativeness in question: The voluntary participants only donated the SMSes of their choice. One could suspect these volunteers of being especially interested in text messaging or in computermediated communication in general. However, one response to this concern would be to emphasise that $40 \%$ of this sample had only been using text messages for a short time, and only infrequently (Err). It might also be thought that the participants only chose particular SMSes: the shortest, the longest, those that protected their privacy, etc. The first argument concerns the number of participants having contributed to our corpus, which, at 115 , was high. It is very unlikely that all of

\footnotetext{
${ }^{5}$ So as to preserve the homogeneity of our sample, one participant was eliminated who, at 17 years of age, had an extremely atypical texting experience (Eof): he had donated 302 messages, far surpassing the number of SMSes typically submitted. He was participant no. 24.
} 
them used the same criteria to make the same systematic choices. Furthermore, from the technical standpoint of the participant, the easiest thing would have been to "donate" the last SMSes they had sent. And, as the analysis showed, this study's corpus is in fact made up of a great variety of text messages. All of these elements, combined with the fact that the SMSes which were studied came from real communications, point to a satisfactory ecological validity of this corpus.

\subsection{Coding}

Below are examples of two original messages which were collected, followed by their conventional written translation in parentheses.

\section{Example 1: Boy, 13 years old, experienced (Eof)}

Original message: Salut mec cmt tva? Jé le nouvo je de sk8 thug2 sper nn a 2 m1 (Hi man hw r u? I got d new sk8 Thug2 gme sper c u tmro)

Message transcribed into standard langage: Salut mec comment tu vas ? J'ai le nouveau jeu de skate Thug2 super non à demain (Hi man how are you? I got the new skate Thug2 game super see you tomorrow)

\section{Example 2: Girl, 18 years old, inexperienced (Err)}

Original message: OK! ms essaye pas tro tar qd $\mathrm{mm}$ kom ca on peu voir le marché de nowel! Travaille bien ms pas tro quand $\mathrm{mm}$ ! A toute, salout'! Me. (OK! But not 2 late cuz thn we can c the Xmas market! Work hard but not 2 much tho! C u soon, bye! Me.)

Message transcribed into standard langage: OK! Mais essaye pas trop tard quand même comme ça on peut voir le marché de Noël! Travaille bien mais pas trop quand même ! À toute, salut ! Me.

\footnotetext{
${ }^{6}$ For participants of both types of experience, the number of messages actually submitted was independent of the number of messages the donors claimed to have sent per week.
} 
(OK! But not too late because then we can see the Christmas market! Work hard but not too much though! See you soon, bye! Me.)

\subsubsection{Quantity index}

For each original message, using the automatic counting formulas in Excel ${ }^{\mathrm{TM}}$, the number of characters (including spaces) ${ }^{7}$ was recorded as well as the number of items (number of words), in other words, strings of letters separated by two spaces (cf. Table 2).

\section{Insert Table 2}

\subsubsection{Function indexes}

As shown by Thurlow and Brown (2003) in a study conducted in English, messages have different functions which can be classified into two categories: informative-transactional or relational. For the latter, we created four sub-categories. The classification of the functions of the body of the messages, followed by an example of each case, is presented below. The body of one message sometimes fit into two categories or several sub-categories of the relational function, i.e., social organisation and friendly relations. Other examples are listed in Table A2 of Appendix A.

\footnotetext{
${ }^{7}$ Although an SMS can not contain more than 160 character including spaces, 46 messages, or $4.07 \%$ of the study corpus, surpassed this limit (161-311 characters with spaces). In fact, when, during the "SMS donation", two SMSes were found to make up one single SMS, they were combined (the average length of the 46 messages was 219.41 with a standard deviation of 55.30).
} 
a) Informative-transactional category: exchanging of practical information and doing favours function

Original message: alors t'as telephoner pr le tit boulot darchives? j'ai oublié de dmanD combien ct payé, tu le c twa? (So DdU cll bout dat job n d archives dept? I 4got 2 ask u hw mch it paid. DY knw?)

Message transcribed into standard langage: Alors tu as téléphoné pour le petit boulot d'archives ? J'ai oublié de demander combien c'était payé, tu le sais toi ? (So did you call about that job in the archives department? I forgot to ask you how much it paid. Do you know?)

b) Relational category

b1) Function: social arrangements

Original message: On sera prob vers 3h30 4moins 15 à waterloo bisous (we'll prolly B @ Waterloo arnd 3:30-3:45)

Message transcribed into standard langage: On sera probablement vers $3 \mathrm{~h} 304$ heures moins 15 à Waterloo bisous (We will probably be at Waterloo around 3:30-3:45 hugs)

b2) Function: ritualised interpersonal exchanges

Original message: je vais bien et toi? Tu racontes koi d'bo? (I'm doiN gr8 n you? What's nu W u?) Message transcribed into standard langage: Je vais bien et toi ? Tu racontes quoi de beau ? (I'm doing great and you? What's new with you?) 
b3) Function: friendly relations

Original message: BOn AnNiVeRsAiRe!J'aurais vraiment pas pu etre là,mais jpense à toi!Jte souhaite une merveilleuse 18ème année!! (HAppy BiRtHdAy! I realy c\%dnt av bn der, bt I'm thinkN of u! I wsh u a 1dfl 18th yr!)

Message transcribed into standard langage: Bon anniversaire ! Je n'aurais vraiment pas pu être là, mais je pense à toi ! Je te souhaite une merveilleuse $18^{\text {ème }}$ année ! (Happy birthday! I really could not have been there, but I'm thinking of you! I wish you a wonderful $18^{\text {th }}$ year!)

b4) Function: love relations

Original message: je taime et $\mathrm{c}$ du plu profon de mon coeur qe je te le di (ILU frm $d$ vry bottom of my hart + I am telin $u$ )

Message transcribed into standard langage: Je t'aime et c'est du plus profond de mon cœur que je te le dis (I love you from the very bottom of my heart and I am telling you)

The coder-agreement index represents the number of communally coded functions relative to the total number of coded functions. Out of a total of 1131 messages, 101 messages, or $8.9 \%$ of the corpus, were double-coded. The mean coder-agreement index was $88.3 \%$.

\section{Results}

A three-factor ANOVA was performed, looking at the effects of age, (13-14, 15-16, and 17-18 years of age), gender (male/female), and experience (old/frequent and recent/rare). In the 13- to 14year-old age group, there was a rather low number of old/frequent boys and corresponding SMSes (cf. Table 1). This illustrated an ecological reality. Text messages (and not participants) were used as units of analysis. Moreover, only simple effects and double interactions (and not triple 
interactions) were taken into account: The number of SMSes being examined was never less than 69. The non-parametric chi-square test (observed values/expected values) was also used. The results were considered significant at .05 .

\subsection{Quantity indexes}

The number of characters (including spaces) - Figure 1 shows the average number of characters in terms of age and gender.

\section{Insert Figure 1}

The factors of age $\left(F(2,1119)=5.41, p<.005, \eta^{2}=.01\right)$ and $\operatorname{gender}(F(1,1119)=12.98, p<$ $\left..0003, \eta^{2}=.01\right)$ were significant as was the age $\mathrm{x}$ gender interaction $(F(2,1119)=9.31, p<.0001$, $\left.\eta^{2}=.02\right)$. On the whole, the number of characters increased with age and was greater for girls than for boys. For girls, this increase occurred between $13-14$ and $15-16$ years of age $(F(1,1119)=47.03$, $p<.00001)$, while for boys, the increase occurred between $15-16$ and $17-18$ years of age $(F(1,1119)$ $=10.58, p<.001)$. For girls, a decrease in the number of characters was noted between the ages of 15-16 and 17-18 $(F(1,1119)=5.76, p<.02)$. At 13-14 years of age, the difference between girls and boys was not significant (approximately 89 characters per message) while it was significant at $15-16$ years of age $(F(1,1119)=42.21, p<.00001)$, with 130 characters for girls and 84 for boys. The difference remained significant at $17-18$ years of age $(F(1,1119)=4.10, p<.05)$, with 118 characters for girls and 107 for boys.

Figure 2 shows the average number of characters according to gender and experience. 
Insert Figure 2

The interaction between gender and experience was significant $\left(F(1,119)=4.44, p<.04, \eta^{2}=\right.$ .004), as the difference between girls and boys was more important in teenagers with old/frequent experience (Eof) than in those with recent/rare experience (Err). In terms of recent/rare experience, the difference was not significant between girls and boys, although it was significant for old/frequent experience $(F(1,119)=11.99, p<.0006)$.

Number of items (number of words) - Figure 3 shows the average number of words according to age and gender.

Insert Figure 3

The gender factor $\left(F(1,1119)=4.27, p<.04, \eta^{2}=.004\right)$ was significant, as was the age $\mathrm{x}$ gender interaction $\left(F(2,1119)=13.31, p<.00001, \eta^{2}=.02\right)$. On the whole, the number of words was greater for girls than for boys. For girls, the increase with age occurred between 13-14 and 15-16 years of age $(F(1,1119)=40.20, p<.00001)$ while for boys, it occurred between $15-16$ and 17-18 years of age $(F(1,1119)=13.07, p<.0004)$. A decrease in number of words with age was noted in girls between $15-16$ and 17-18 years of age $(F(1,1119)=10.80, p<.001)$. At 13-14 years of age, the difference between girls and boys was not significant (about 19 words per message) but it was significant at the ages of $15-16(F(1,1119)=36.59, p<.00001)$ : 25 words for girls and 17 for boys. The difference was not significant at 17-18 years of age (about 22 words per message). 


\subsection{Message function indexes}

Table 3 indicates the distribution of the different functions present within the message body. The number of messages with a "relational" function was significantly greater than the number of messages containing an "informative-transactional" function $\left(\chi^{2}(1)=12.48, p<.001\right)$.

\section{Insert Table 3}

Within the "relational" function (cf. Table 3) the difference between the 4 sub-categories was also significant $\left(\chi^{2}(3)=64.02, p<.0001\right)$. In decreasing order, the function distribution resulted in friendly relations and social arrangements (about 35\% for each category) followed by love relations and ritualised interpersonal exchanges (approximately 15\% for each sub-category). Table 4 shows that the distribution presented in table 3 (a superiority of the "relational" function as compared to the "informative-transactional" function) was only true for teenagers between the ages of 15-16 $\left(\chi^{2}(1)=7.48, p<.01\right)$, for girls $\left(\chi^{2}(1)=10.56, p<.01\right)$, and for teenagers with old/frequent SMS experience $\left(\chi^{2}(1)=13.76, p<.001\right)$. The difference between the two functions was not significant for 13- to 14-year-old and 17- to 18-year old teenagers, for boys in general, and for recent/rare experience with text messaging. The distribution presented in Table 3 detailing the difference between the 4 categories of messages with a relational function is true for 13- to 18 -year old teenagers, for girls and boys, and for both experienced and inexperienced users.

\section{Insert Table 4}

In Figure 4, the analysis goes deeper by noting the percentage of informative and relational functions in the body of the messages with regard to age, gender and experience. 
Insert Figure 4

There was a difference between the profiles of girls and boys. Regarding old/frequent experience, the function of 15- to 16-year-old girls' messages was more relational than informative $\left(\chi^{2}(1)=10.07, p<.001\right)$, while this did not appear in boys until much later, around 17-18 years of age $\left(\chi^{2}(1)=4.01, p<.01\right)$. On the other hand, in terms of recent/rare experience, there was no significant difference between girls and boys.

\section{Discussion}

This study examined a corpus of 1131 SMS messages produced by 115 participants in a natural situation. The reliable methodology by which the messages were collected prevented both retranscription errors and the over-representation of short messages. The principal results of this research are described below.

First of all, with regard to the quantity index (number of characters with spaces), on the whole, between the ages of 13 and 18, the number of characters increased with age and this increase was greater in girls than in boys. However, the developmental trajectory for both genders was not the same: for girls, the increase took place between the ages of 13-14 and 15-16, while for boys, it occurred later, between the ages of 15-16 and 17-18. The difference between girls and boys was not significant at 13-14 years of age, but starting at age 15. Another important result showed that the difference between girls and boys only existed for teenagers with old/frequent (Eof) experience; no difference was noted for the adolescents who had recent/rare (Err) experience. On average, message length fell between 90 and 130 characters. The second quantity index (number of words) showed similar results. On the whole, between 13 and 18 years of age, the number of words was again 
greater for girls than for boys. However, the developmental trajectory not being identical for the two genders, the increase in words took place in girls between 13-14 and 15-16 years of age, while in boys, it appeared later, between the ages of 15-16 and 17-18. The difference between boys and girls was only significant at 15-16 years of age. The average message length was between 17-25 words.

For the function indexes, the first result showed that the study's function grid was validated by two coders, thus making it possible to obtain an overall proportion of coder agreement surpassing $80 \%$. Relational message functions (approximately 60\%) were more frequent than transactionalinformative message functions (about 40\%) in the case of 15- to 16-year-old teenagers, for girls, and for teenagers with old/frequent text-messaging experience. The dominant relational functions were friendly relations and social arrangements (about 35\% each), although the functions of love relations and ritualised interpersonal exchanges were also noted. Finally, in terms of gender differences, the results showed that in teenagers with old/frequent SMS experience, messages sent by girls had a more relational than informative function starting at the age of 15-16 years, while the same phenomenon only occurred in boys at the age of 17-18. No difference was noted between girls and boys, however, when their texting experience was recent/rare.

These results bring new and complementary data to the existing research. In a general sense, this study analysed a coherent set of SMS messages produced by French-speaking teenagers between the ages of 13 and 18. The analysis of this age range already exists in English (Grinter \& Eldridge, 2001; Thurlow \& Brown, 2003), Norwegian (Ling, 2005a and 2005b), isiXhossa (Deumert \& Masinyana, 2008), German (Döring et al., 2005) and Finnish (Kasesniemi, 2003).

As for message length, the results of this study (90-130 characters and 17-25 words), obtained from a large, natural corpus which had been forwarded to a server by the participants, are closer to those results obtained by a small group of participants who were known to the researchers (65-133 
characters and 14-22 words, Deumert \& Masinyana, 2008; Grinter \& Eldridge, 2001; Thurlow \& Brown, 2003) than those obtained from a phone survey conducted across a wide number of participants (29 letters and 6 words, Ling, 2005a and 2005b). For the first time, these results take into account a subtle change related to age, gender, and SMS experience, showing that, while girls' messages are certainly longer than those of boys, it is essentially at 15-16 years of age and with those girls whose texting experience is old/frequent. Girls and boys have different developmental trajectories: Girls progress between 13-14 and 15-16 years of age, while for boys this change happens later, between 15-16 and 17-18 years of age. This data modalises Ling's (2005a and 2005b) findings, that girls' messages are longer and more complex than those produced by boys, which were confirmed by the findings of Volckaert-Legrier et al. (2009), whose study demonstrated the effect of experience on the production of e-mail messages (in terms of orthographic forms). Moreover, it must be noted that at the same age, teenagers have not yet finished acquiring the skills to write in the traditional form (Berman, 2005): In terms of traditional writing, they are capable of writing texts of several pages in length, moving into the use of the passive voice, lexical diversity, and a variety of textual styles (narrative or expository) and verb tenses.

With regard to the message functions, the results of this study concur with those of Thurlow and Brown (2003), as well as with the existing research already conducted on the importance of relational functions. However, as with the quantity indexes, this study showed that the distribution of informative/relational functions varied according to the characteristics of the message-writer: The relational function was only dominant in 15- to 16-year-old teenagers, in girls, and in teenagers with old/frequent experience. Additionally, in both informative and relational functions, the grid validated in this study obtained a high level of inter-coder agreement; this validation was not achieved in other previous studies. The distribution of informative (40\%) and relational (60\%) functions revealed within SMS messages can be compared to the one observed in other modes of 
interpersonal computer-mediated communication: in oral form by mobile or land-line telephone or by video chat, and in written form by chat or on social networks (i.e., Facebook, Twitter), etc. Furthermore, it is the link between the SMS functions and their linguistic characteristics (length, dialogue structure, but also orthographic form), which will eventually aid the most in furthering the knowledge of written SMS messages.

\section{Conclusion}

This study showed that the characteristics of the text-message writer play a role in the length and function of SMS messages. Girls seem especially more prolific than boys in the writing of their SMSes. Beyond this quantitative aspect, this study's data also suggest that the messages girls send are more relational (social arrangements, news requests, friendly and love relations) than informative (exchanging practical information and doing favours) and that this is the case as early as 15-16 years of age. This is also the case for boys, but later, as this type of difference is not observed in them until 17-18 years of age. For message length or message function, the difference between girls and boys seems to be linked to a developmental gap which can also be observed in other areas during this age period (Lehalle, 1995; Marcelli \& Braconnier, 2008). In essence, a difference, whether quantitative or qualitative, between girls and boys can be noted at 15-16 years of age and in those teenagers with old/frequent SMS experience. In sum, our data confirm that a difference does indeed exist between boys and girls. But our results indicate that this difference is mitigated on the one hand by age, and on the other hand by experience.

With the aim of furthering our knowledge of the written SMS, additional studies will be necessary, especially taking into account the relation between the function and the length of text messages. Furthermore, as found by Spagnolli and Gamberini (2007), certain characteristics of SMS messages are dependent upon the messages which precede them, and additional studies will be 
necessary to examine the turn-taking sequence between two SMS-writers. The results of this study underline the complexity of SMS-messaging, lending support to Crystal's (2001) proposition that computer-mediated communication should be considered as a specific register of its own, different from traditional oral communication, written communication, or sign language. Contrary to the three other large registers, computer-mediated communication is not stable, and the extremely rapid evolution which it is currently experiencing makes it difficult for researchers to capture.

\section{Conflict of interest: none.}

\section{Acknowledgements}

This study was supported by the French National Research Agency (ANR) study "Adolescents and computer-mediated communication: pre-requisites, uses and learning” (ANR-08-COMM-011-01). Special thanks are extended to Martha Randy for translating this paper

\section{Appendix A. Supplementary data}

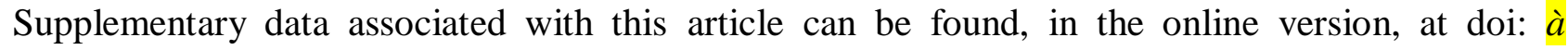
compléter.

\section{References}

Anis, J. (2007). Neography: Unconventional spelling in French SMS text messages In B. Danet,. \& S.C. Herring, (Eds.), The multilingual internet: Language, culture and communication on line. (pp. 87-115). New York: Oxford University Press.

Austin, J.L. (1962). How to do things with words. Cambridge, Massachusetts: Harvard University Press. 
Bernicot, J. (1994). Speech acts in young children: Vygotski's contribution. European Journal of Psychology of Education, 9, 311-320.

Bernicot, J., Comeau, J., \& Feider, H. (1994). Dialogues between French-speaking mothers and daughters in two cultures: France and Quebec. Discourse Processes, 18, 19-34.

Bernicot, J., Laval, V. \& Chaminaud, S. (2007). Nonliteral Language Forms in Children: In What Order Are They Acquired in Pragmatics and Metapragmatics? Journal of Pragmatics, 39, 21152132.

Berman, R.A. (2005). Introduction: Developing discourse stance in different text types and languages. Journal of Pragmatics, 37(2), 105-124.

Bigot, R. \& Croutte, P. (2009). La diffusion des technologies de l'information et de la communication dans la société française. Paris : CREDOC.

Bouillaud, C., Chanquoy, L. \& Gombert, J.-E. (2007). Cyberlangage et orthographe : quels effets sur le niveau orthographique des élèves de CM2, $5^{\mathrm{e}}$ et $3^{\mathrm{e}}$ ? Bulletin de Psychologie, 60(6), 553565.

Brown, A. (2002). The language and communication of SMS: An exploratory study of young adults' text-messaging. Unpublished BA dissertation, Cardiff University.

Crystal, D. (2001). Language and Internet. Cambridge: Cambridge University Press.

Crystal, D. (2008). Txtng: the gr8 db8. Oxford: Oxford University Press.

Danet, B. \& Herring, S. C. (2007). Multilingualism on the Internet. In M. Hellinger \& A. Pauwels (Eds.), Language and Communication: Diversity and Change. Handbook of Applied Linguistics 9. Berlin: Mouton de Gruyter. 
Deumert, A. \& Masinyana, S.O. (2008). Mobile language choices. The use of English and isiXhosa in text messages (SMS): Evidence from a bilingual South African sample. English World-Wide, 29(2), 117-147.

Döring, N., Hellwig, K. \& Klimsa, P. (2005). Mobile Communication among Youth in Germany. In K. Nyiri (Ed.), A Sense of Place: The Global and the Local in Mobile Communication (pp. 209220). Wien: Passagen Verlag.

Fairon, C. \& Klein, J.R. (2010). Les écritures et graphies inventives des SMS face aux graphies normées. Le français d'aujourd'hui. Graphies : signes, gestes, supports. 170, 113-122.

Fairon, C., Klein, J.R. \& Paumier S. (2006). SMS pour la science. Corpus de 30.000 SMS et logiciel de consultation. Louvain-la-Neuve : Presses Universitaires de Louvain.

Faulkner, X. \& Culvin, F. (2005). When fingers do talking: a study of text messaging. Interacting with computers, 17, 167-185.

Favre, D., Joly, J., Reynaud, C. \& Salvador, L.-L. (2009). Empathie, contagion émotionnelle et coupure par rapport aux émotions : validation d'un test pour repérer et aider des élèves a risque. Revue Europeenne de Psychologie Appliquee/European Review of Applied Psychology, 59(3), 211-227.

Frehner, C. (2008). Email - SMS - MMS: the linguistic creativity of asynchronous discourse in the media age. Studies in Language and Communication, Vol. 58. Bern: Peter Lang.

Gadet, F. (2007). L'oral et l'écrit dans les changements technologiques et idéologiques. In E. Galazzi \& C. Molinari (Eds.), Les français en émergence (pp. 131-142). Berne : Peter Lang.

Gleason, J. B. \& Ely, R. (2002). Gender differences in language development. In A.M. De Lisi \& R. De Lisi (Eds.), Biology, society, and behavior: The development of sex differences in cognition (pp. 127-154). Westport, CT: Ablex. 
Grice, P. (1975). Logic and conversation. In P. Cole \& J. Morgan (Eds.), Syntax and Semantics 3: Speech Acts (pp. 41-58). New York: Academic Press.

Grinter, D.E. \& Eldridge, M.A. (2001). Y do tngrs luv 2 txt msg? In W. Prinz, M. Jarke, Y. Rogers, K. Schmidt \& V. Wulf (Eds.), Proceedings of the seventh European Conference on ComputerSupported Cooperative Work (pp. 219-238), Netherlands: Kluwer Academic Publishers.

Halpern, D. F. (2000). Sex differences in cognitive abilities (3rd ed.). Mahwah, NJ: Erlbaum.

Hård af Segerstad, Y. (2005). Language Use in Swedish Mobile Text Messaging. In R. Ling \& P. E. Pedersen (Eds.), Mobile Communications: Re-negotiation of the social sphere (pp. 313 - 334). London: Springer.

Kasesniemi, E.L. (2003) Mobile messages: Young people and a new communication culture. Tempere, Finland: Tampere University Press.

Leaper, C. \& Smith, T.E. (2004). A Meta-Analytic Review of Gender Variations in Children's Language Use: Talkativeness, Affiliative Speech, and Assertive Speech, Developmental Psychology, 40(6), 993-1027.

Lehalle, H. (1995). Psychologie des adolescents. Paris : Presses Universitaires de France

Leo \& Wolf SA. (2004). Retrieved 22 April 2010 from http://www.serialwireless.net/+70-des-1535-ans-acceptent-de, $343+$.html

Liénard, F. (2005). Langage texto et langage contrôlé : Description et problèmes. Linguisticae Investigationes, 27, 1, 49-60.

Liénard, F. (2007). Analyse linguistique et sociopragmatique de l'écriture électronique. Le cas du SMS tchaté. In J. Gerbault (Ed.), La langue du cyberespace : de la diversité aux normes (pp. 265-278). Paris : l'Harmattan.

Ling, R. (2005 a). The length of text messages and the use of predictive texting: Who uses it and 
how much do they have to say? Paper presented at the Association of Internet Researchers, Chicago, IL.

Ling, R. (2005 b). The socio-linguistics of SMS: An analysis of SMS use by a random sample of Norwegians. (pp. 335-349). In R. Ling and P. E. Pedersen (Eds.), Mobile communications: Renegotiation of the social sphere. London: Springer.

Marcelli, D. \& Braconnier, A. (2008). Adolescence et psychopathologie. Paris : Masson.

McCarthy, D. (1954). Language development in children. In P. Mussen (Ed.), Carmichael's manual of child psychology. New-York: Wiley and Sons.

Michaud, J., Begin, H. \& McDuff, P. (2006). Construction et évaluation d'un questionnaire sur l'estime de soi sociale destiné aux jeunes adultes. Revue Europeenne de Psychologie Appliquee/European Review of Applied Psychology, 56(2), 109-122

Noveck, I. \& Sperber, D. (2004). Experimental Pragmatics. Basingstoke, England: Palgrave.

Panckhurst, R. (1997). La communication médiatisée par ordinateur ou la communication médiée par ordinateur? Terminologies nouvelles, 17, 56-58.

Panckhurst, R. (2009). Short Message Service (SMS) : typologie et problématiques futures. In T. Arnavielle (Ed.), Polyphonies, pour Michelle Lanvin. (pp.33-52). Université Paul-Valéry Montpellier 3.

Puustinen, M., Bernicot, J. \& Bert-Erboul, A. (2011). Written Computer-Mediated Requests for Help by French-Speaking Students: An Analysis of Their Forms and Functions. Learning and Instruction, 21, 281-289.

Puustinen, M., Volckaert-Legrier, O., Coquin, D. \& Bernicot, J. (2009). An analysis of students' spontaneous computer-mediated help seeking: A step toward the design of ecologically valid supporting tools. Computers \& Education, 53, 1040-1047. 
Ravid, D. \& Tolchinsky, L. (2002). Developing linguistic literacy: a comprehensive model. Journal of child language, 29, 2, 417-447.

Rivière, C.A. \& Licoppe, C. (2005). From voice to text: Continuity and change in the use of mobile phones in France and Japan. In R. Harper, L.A. Palen \& A. Taylor (Eds.), The inside text: Social, cultural and design perspectives on SMS, vol. 4 (pp. 103-126). Dordrecht, The Netherlands: Springer.

Samsung (2006). Le comportement mobile belge décortiqué par Samsung. Retrieved 22 April 2009. http://www.bemobile.be/2006/08/17/le-comportement-mobile-belge-decortique-par-samsung/

Searle, J.R. (1969). Speech acts. Cambridge, MA: Cambridge University Press.

Searle, J.R. \& Vanderveken, D. (1985). Foundations of illocutionary logic. Cambridge: Cambridge University Press.

Spagnolli, A. \& Gamberini, L. (2007). Interacting via SMS: Practices of social closeness and reciprocation. British Journal of Social Psychology, 46, 343-364.

Thurlow, C. \& Brown, A. (2003). Generation Txt? The sociolinguistics of young people's text$\begin{array}{llllll}\text { messaging. } & \text { Retrieved } & 28 & \text { July } & 2010 & \text { from }\end{array}$ http://faculty.washington.edu/thurlow/papers/Thurlow(2003)-DAOL.pdf

Thurlow, C. \& Poff, M. (2009). The language of text messaging. In S.C. Herring, D. Stein \& T. Virtanen (Eds.), Handbook of the pragmatics of CMC. Berlin and New York: Mouton de Gruyter.

Véronis, J. \& Guimier de Neef, E. (2006). Le traitement des nouvelles formes de communication écrite. In G. Sabah (Ed.), Compréhension automatique des langues et interaction (pp.227-248.). Paris : Hermès Science.

Verschueren, J. (1999). Understanding pragmatics. London: Arnold. 
Volckaert-Legrier, O. (2007). Le courrier électronique chez les adolescents : un nouveau registre de la langue écrite. Thèse de doctorat : Université de Poitiers.

Volckaert-Legrier, O., Bernicot, J. \& Bert-Erboul, A. (2009). Electronic mail, a new writtenlanguage register: a study with French-speaking adolescents. British Journal of Developmental Psychology, 27, 163-181.

Wood, J. T. (2001). Gendered lives: Communication, gender, and culture (4th ed.). Belmont, CA: Wadsworth. 
Table 1

Number of Participants and SMS Messages According to Age, Gender and Experience.

Number of participants

\begin{tabular}{cccccccc}
\hline \multirow{2}{*}{ Age } & \multicolumn{6}{c}{ Old/frequent experience (Eof) } & \multicolumn{3}{c}{ Recent/rare experience (Err) } & \multirow{2}{*}{ Total } \\
\cline { 2 - 6 } & Male & Female & Total Eof & Male & Female & Total Err & \\
\hline $13-14$ & 2 & 6 & 8 & 9 & 6 & 15 & 23 \\
$15-16$ & 13 & 12 & 25 & 7 & 9 & 16 & 41 \\
$17-18$ & 16 & 20 & 36 & 7 & 8 & 1 & 51 \\
\hline Total & 31 & 38 & 69 & 23 & 23 & 46 & 115 \\
\hline
\end{tabular}

Number of SMS Messages

\begin{tabular}{cccccccc}
\hline \multirow{2}{*}{$\begin{array}{c}\text { Age } \\
\text { (number) }\end{array}$} & \multicolumn{2}{c}{ Old/frequent experience (Eof) } & \multicolumn{3}{c}{ Recent/rare experience (Err) } & \multirow{2}{*}{ Total } \\
\cline { 2 - 6 } & Male & Female & Total Eof & Male & Female & Total Err & \\
\hline $13-14(23)$ & 4 & 107 & 111 & 65 & 51 & 116 & 227 \\
\hline $15-16(41)$ & 108 & 155 & 263 & 22 & 51 & 73 & 336 \\
\hline $17-18(51)$ & 235 & 193 & 428 & 42 & 98 & 140 & 568 \\
\hline Total (115) & 347 & 455 & 802 & 129 & 200 & 329 & 1131 \\
\hline
\end{tabular}


Table 2

Quantity-coding examples

G oublié de dmanD son num à charlène tu px me

Ben la je ss ds le bus et je le donné?Pq tu di ke ça colle blentre ns?Moi jss serai rentré ds $1 / 4 \mathrm{~h}+/-\quad$ ds mn li ac mn lecteur mp3à fon!Rp stp!!Jtad.Ton

Original pq?(Well I'm in the bus pti chou (I forgot to ask Charlène for her number

SMS and I'll be home in 15 can you give it to me? Why do you say that there

minutes more or less are sparks between us? I'm in my bed with my

why?) MP3 player blasting! Write back please! I adore

you. Your little honey)

Number of

characters

Number of

words 
Table 3

Number (and Percentage) of Occurrences of Different Functions within Message Bodies.

Comparison of informative-transactional and relational functions

\begin{tabular}{cccc}
\hline & $\begin{array}{c}\text { Informative and transactional } \\
\text { Function }\end{array}$ & \multicolumn{2}{c}{ Relational (number of } \\
& (Exchanging practical information \\
& and doing favours) & messages containing at least & Total \\
& $\mathrm{N}=569$ & $\mathrm{~N}=750$ & \\
\hline Number & $(43.14 \%)$ & $(56.86 \%)$ & 1319 \\
(Percentages) & & & \\
\hline
\end{tabular}

Comparison of Sub-categories of the Relational Function

\begin{tabular}{cccccc}
\hline Sub- & Social & Ritualised & Friendly & Love & \\
categories & organisation & interpersonal & Total \\
exchanges & relations & relations & \\
\hline Number & $\mathrm{N}=282$ & $\mathrm{~N}=123$ & $\mathrm{~N}=302$ & $\mathrm{~N}=140$ & $\mathrm{~N}=$ \\
(Percentages) & $(33.29 \%)$ & $(14.52 \%)$ & $(35.66 \%)$ & $(16.53 \%)$ & 847 \\
\hline
\end{tabular}


Table 4

Number (and percentages) of occurrences of different functions within message bodies in terms of age, gender, and experience. Bold characters indicate significant differences.

\begin{tabular}{cccc}
\hline & & Relational (number of & \\
Functions & Informative- & messages containing at & Total \\
& transactional & least one relational & number \\
& & category) & \\
\hline $13-14$ years & $121(42.91 \%)$ & $161(57.09 \%)$ & 282 \\
\hline 15-16 years & $\mathbf{1 5 7 ( 4 0 . 2 6 \% )}$ & $\mathbf{2 3 3}(\mathbf{5 9 . 7 4 \% )}$ & $\mathbf{3 9 0}$ \\
\hline $17-18$ years & $291(44.98 \%)$ & $356(55.02 \%)$ & 647 \\
\hline Male & $248(45.09 \%)$ & $302(54.91 \%)$ & 550 \\
\hline Female & $\mathbf{3 2 1 ( 4 1 . 7 4 \% )}$ & $\mathbf{4 4 8}(\mathbf{5 8 . 2 6 \% )}$ & $\mathbf{7 6 9}$ \\
\hline Old/frequent experience & $\mathbf{3 7 8 ( 4 1 . 3 6 \% )}$ & $\mathbf{5 3 6}(\mathbf{5 8 . 6 4 \% )}$ & $\mathbf{9 1 4}$ \\
\hline Recent/rare experience & $191(47.16 \%)$ & $214(52.84 \%)$ & 405 \\
\hline
\end{tabular}


Figures Titles

Figure 1. Average number of characters per message in terms of age and gender (Vertical bars indicate the standard deviation values).

Figure 2. Average number of characters per message in terms of participants' gender and texting experience (Vertical bars indicate the standard deviation values) (Err: recent/rare experience; Eof: old/frequent experience).

Figure 3. Average number of words per message in terms of participants' age and gender (Vertical bars indicate the standard deviation values).

Figure 4. Percentage of occurrences of informative and relational functions in message bodies in terms of age, gender, and experience. 
Appendix A

Table A1

Number of Participants in Terms of Number of Messages Sent and Messaging Experience.

\begin{tabular}{lccc}
\hline \multicolumn{2}{c}{ Old/frequent experience (Eof) } & \multicolumn{2}{c}{ Recent/rare experience (Err) } \\
\hline 10-20 SMS/week & 37 & Less than 5 SMS/week & 17 \\
20-50 SMS/week & 23 & Between 5-10 SMS/week & 29 \\
50->100 SMS/week & 9 & & \\
\hline
\end{tabular}


Table A2

Examples of Message Bodies with Classification of their Functions.

Function Informational-transactional

Example

Pq tu dors parterre? Charlène dort ds ton lit?Di lui bonne nuit et donne moi son numéro de gsm stp. (Why are you sleeping on the ground? Is Charlène sleeping in your bed? Tell her good night and give me her GSM number please.)

\begin{tabular}{ll}
\hline Function & \multicolumn{1}{c}{ Social arrangements } \\
\hline Sub-category & \multicolumn{1}{c}{ Ritualised interpersonal } \\
\hline & Tu px venir chez moi a 9h15 on doi allé coment ale vous koi d9 (How \\
& cherche des amies à moi donc on y sera un are you doing what's up?) \\
& peu avan 10h mai je revien avec elle donc \\
& Dsl pr le retour. (Can you come to my \\
Example & place at 9:15 we have to go get my friends \\
& so we'll be there a little before 10:00 but \\
& I'm coming back with her so sorry for the \\
& ride back.)
\end{tabular}

\begin{tabular}{lll}
\hline Sub-category & \multicolumn{1}{c}{ Friendly relations } & \multicolumn{1}{c}{ Love relations } \\
\hline & On sera tjr la ne loublie pas et puis je serai & Je t aime mon Amour fait de \\
Example & près de toi tantot (We'll always be there & beau reve je Pense a toi (I love \\
& don't forget it and I'll be with you soon) & you my love sweet dreams i'm \\
& & thinking of you)
\end{tabular}

